\title{
SOCIAL ASPECT OF LEISURE AMONG THE TRIBAL POPULATION OF NAGARHOLE NATIONAL PARK, KARNATAKA
}

\author{
R. Raju, ${ }^{*}$ G. Saraswathi, ${ }^{* *}$ K.N. Baidya***
}

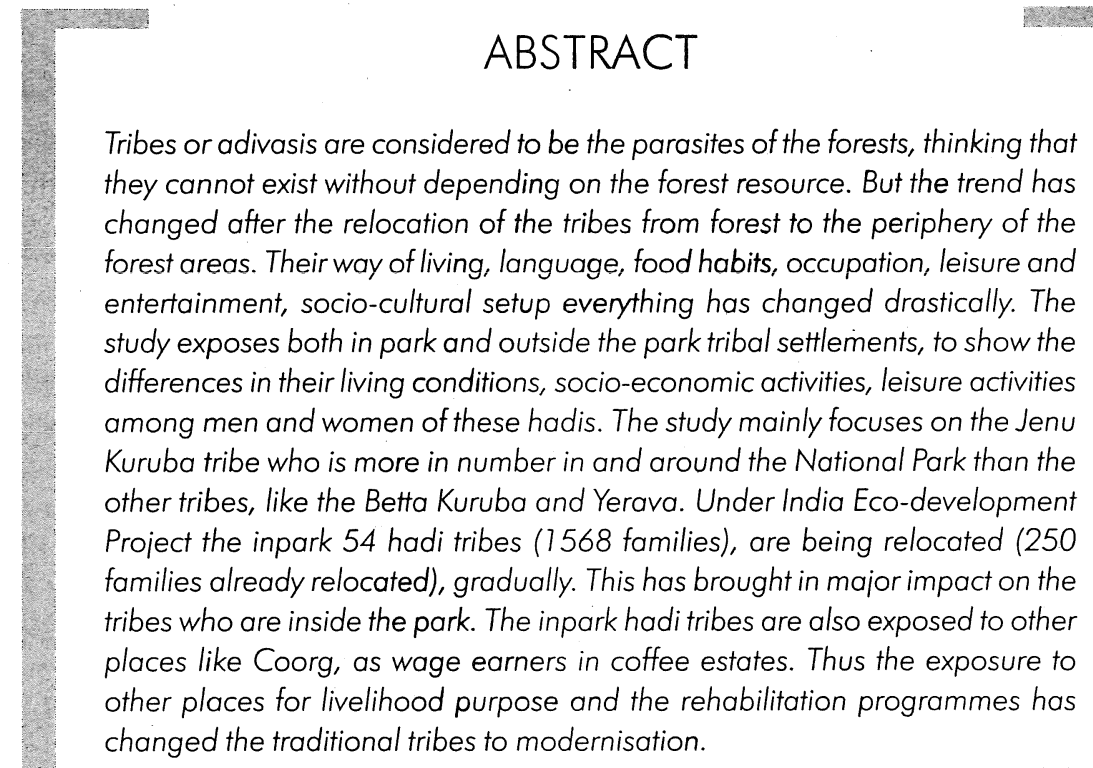

* Deputy Conservator of Forests, Aranya Bhavan, Mysore.

** Women Development Officer, IEDP, Nagarahole.

*** Retd. Chief Conservator of Forests, Bangalore. 


\section{Key words:}

Nagarahole National Park, Hadi, Tribes, Leisure, Jenu Kuruba, Ashram

School, and Social aspect.

\section{Introduction}

The tribes are believed to be the original inhabitants and caretakers of the forests, who are locally known as 'Moolanivasis' or 'Adivasis'. Nagarahole National Park also known as Rajiv Gandhi National Park (renamed in May 1992), is situated in Mysore and Kodagu districts of Karnataka State, South India. The tribals constitute $8 \%$ of India's total population and form the majority of 1/6th of the national population that migrates every year. The tribal population in Karnataka constitutes $4.26 \%$ of the State population (1991) and there are 49 different Scheduled Tribes in our state. The tribal communities in Karnataka consist mainly of the Jenu-Kurubas, Betta Kurubas, (Kadu Kurubas), Soligas, Hakki Pikki, Koragas, Yeravas (PaniyaYerava, Panjari-Yerava), Irulas, Hasalaru, Male Udiya and Marava.

Our study restricts to Jenu-Kuruba, (Kadu-Kuruba and Yeravas) who are mainly found inside the Park, as well as the Periphery of the National Park area. Earlier, the tribes were only food gatherers, like the collection of honey and wax being the traditional right of the Jenu Kurubas, and the collection of other forest produce is the traditional right of Betta Kurubas. Forest is their eternal source of livelihood and they are the parasites of the forest and cannot exist away from it was their principle. But, now the situation has changed, they are exposed to the influence of modern society and are working as labourers in agriculture, plantations, masonry, and some are also agriculturists by themselves. Rehabilitation or relocation from their forest habitats, construction of dams, laying of roads, declaration of forests as National Park / Wild Life Sanctuaries, etc., are some of the reasons for their exposure to the outer world.

This in addition to the changing of their traditional value system, have also changed their socio-cultural setup like, the dress pattern, food habits, use of cosmetics, change in spoken language, adoption of family planning methods, education of the children, and so on. In this paper, we are interested to see the impact of modern culture in their 'attitude to leisure activities'. This impact is studied in two variations like, the Hadis located in the interior forest area (who are not exposed), and those Hadis located in the periphery of the forest area (who are exposed to the neighboring villages). 


\section{Main Objectives:}

1. To study the social aspect of the leisure among tribes of Nagarahole National Park.

2. Variation between the leisure activities of men and women.

3. Variation between the tribes who have settled inside the park hadis and those who have settled outside the park hadis.

4. Their life style, living pattern, health, hygiene, habits etc.,

\section{Methodology}

It is a sample survey from both inpark and outside the park hadis. The total number of persons interviewed is 30 male and 30 female i.e., 10 from each hadi to see the variations. Data collection was performed personally by interviewing both men and women, of all age categories, filling up schedules, observing their dress pattern, housing condition, leisure activities, health and hygiene, child care etc., and involved in group discussion. The following tribal hamlets were visited for the study purpose.

1. Bavikere Hadi, (Sarangur Taluk)

2. Kebbepura Hadi (Katwal Hadi, H.D. Kote Taluk)

3. Anemalada Hadi (H.D. Kote Taluk)

4. Balle Hadi (H.D. Kote Taluk)

5. Timmanahosahalli Hadi (H.D. Kote Taluk)

6. Hosahalli Hadi (H.D. Taluk)

1. Type of Tribe

\begin{tabular}{|l|c|c|}
\hline Tribe & Male & Female \\
\hline Jenu Kuruba & 25 & 25 \\
Bettakuruba & 03 & 03 \\
Yerava & 02 & 02 \\
\hline Total & 30 & 30 \\
\hline
\end{tabular}


1 (a). Tribal Hamlets Visited

\begin{tabular}{|c|l|c|c|c|}
\hline $\begin{array}{c}\text { SI. } \\
\text { No. }\end{array}$ & \multicolumn{1}{|c|}{ Name of the Hadi } & $\begin{array}{c}\text { No. of } \\
\text { Families } \\
\text { Interviewed }\end{array}$ & $\begin{array}{c}\text { No. of } \\
\text { Male }\end{array}$ & $\begin{array}{c}\text { No.of } \\
\text { Female }\end{array}$ \\
\hline 1. & Anemala Hadi & 10 & 05 & 05 \\
2. & Thimmana Hosahally Hadi D.B. Kuppe & 10 & 05 & 05 \\
3. & Balle Hadi & 10 & 05 & 05 \\
4. & Bavikere Hadi & 10 & 05 & 05 \\
5. & Kebbepura Hadi (Katwal hadi) & 10 & 05 & 05 \\
6. & Hosahally Hadi & 10 & 05 & 05 \\
\hline \multicolumn{2}{r|}{} & 60 & 30 & 30 \\
\hline
\end{tabular}

\section{Tribal Communities inside the Park}

There are 54 tribal Hadis (hamlets) inside the Park accounting for more than 1,568 families and a population of more than 6,254 tribes. The tribes residing inside the Park consists of Jenu Kurubas (honey gatherers), Betta Kurubas also known as Kadu Kurubas, Hakki Pikki (bird trappers) and Yeravas (cultivators). These tribes speak Kannada and also a mixed language (of Kannada, Malayalam, Tamil), called Jenu Nudi.

For the different tribal groups of the region the specific economic pursuit appears to be the traditional element. Collection of honey and wax is the traditional right of the Jenu Kurubas and the collection of other forest produce is the traditional right of the Betta Kurubas.

Once upon a time the tribes, who were known as hunters and food gatherers, lived a nomadic life. Now they are mainly labourers and cultivators and their subsidiary occupation is food gathering. When they are free without any other work, they go in search of tubers, honey fruits and dry wood for fuel and basic sustenance. Though technically collecting forest produce is illegal in the park, tribal do gather various non-timber products.

\section{Location and Population}

The Jenu Kurubas are mostly concentrated in the Southern border of Mysore and Coorg district and constitute one of the most backward communities in that region. 
Jenu Kuruba is found mainly in Heggadadevana Kote, Gundlupet, Hunsur and Periyapatna taluks of Mysore district and Mercara, Virajapet and Somawarpet taluks of Coorg district. The area of their concentration is in and around the forest and hill tracts. Forest was their eternal source of livelihood and they were the parasites of the forest and couldnot exist away from it, were the situation of this tribe until 1961.

But, now the Jenukurubas of Nagarahole are also seen working in coffee plantations as daily wage labourers. Some women are observed to be sitting idle, taking care of their children and chitchatting with other neighbourers.

They say that only during rainy season they have handful of work, otherwise they are always idle. The Forest Department employes some men as forest watchers, firewatchers and labourers in forestry activities. Others also work as agricultural labourers.

\section{Age of the respondent}

\begin{tabular}{|c|c|c|}
\hline \multicolumn{3}{|c|}{ Age } \\
\hline Years & Male & Female \\
\hline $20-24$ & 00 & 03 \\
$25-29$ & 06 & 11 \\
$30-34$ & 04 & 02 \\
$35-39$ & 04 & 06 \\
$40-44$ & 07 & 01 \\
$45-49$ & 04 & 03 \\
$50-54$. & 02 & 01 \\
$55-59$ & 02 & 00 \\
$60-64$ & 01 & 02 \\
$65-69$ & 00 & 01 \\
\hline Total & 30 & 30 \\
\hline
\end{tabular}

For the study purpose, we have interviewed all age categories of both male and female, to take different opinion from different categories.

\section{Family and Kinship}

They "do not have clans but they do speak of jamma or gumpa (literally meaning groups)". Nuclear family consisting of husband, a wife and unmarried child is the common family type found among them (Misra: 1975). Early marriage is preferred, 
between the age of 14-18 years. There is no age restriction for male, but preferably between the age of 18-20 years. After marriage the newly wedded couple stats to live independently. Marriage with one's father's sister's daughter, mother's brother's daughter and elder sister's daughter is practised among them.

Family among Jenu Kurubas is patrilineal. The females go to stay with their husbands after marriage. A male member is always the head of the family and his decisions regarding religious, social and economic matters are final. The authority of the head of the family is hardly ever questioned. All the adult females in the family are only assisting hands and their earnings are pooled together for the common expenditure of the household. In religious performances females do not take part. Male equigeniture is the rule of inheritance, while the rule of succession demands that the eldest son should succeed his father.

\section{Family Type}

\begin{tabular}{|l|c|c|}
\hline Type of family & Male & Female \\
\hline Joint & $05(1.5)$ & $01(0.3)$ \\
Nuclear & $25(7.5)$ & $29(9.5)$ \\
\hline Total & 30 & 30 \\
\hline
\end{tabular}

\section{Literacy and Education}

Literacy among Jenu Kurubas is very low. In the state as a whole only $4.89 \%$ of the Jenu Kurubas are literate. When compared with the average literacy of the Scheduled Tribes of the State $8.1 \%$ it becomes obvious that the Jenu Kurubas are educationally very backward. Formal education is favoured for boys and to a certain extent for the girls. There are number of dropouts among the Jenu Kuruba students due to economic reasons. Residential schools impart primary education to the Jenu Kuruba children.

The ashram school inside the hadi provides primary education, but they are not recognisea and act as a basic foundation. Mid-day meal facility is provided in all ashram schools like Sunkadakatte, may be a motivating factor for the children to attend regularly. Two sets of uniform, soaps to wash them and books, slates and chalk pieces are to be provided. Charts and maps which are durable and a regular big black board are to be provided. The teacher who is handling the ashram school, should be a resident of the same hadi or village and in order to motivate him, he should be provided regular salary, meal facility along with the children.

The teacher should also train them to take regular bath, wear clean clothes, keep the school and environment clean, which improves their health condition. 
Thus, informal education should be made compulsory in all the hadis, wherein, the government should provide uniform, mid-day meal, books etc. In order to improve their educational standard, residential schools beyond primary level up to college, or technical orientation courses should be provided to young boys and girls who are interested, which provides them employment opportunities.

\section{Education}

\begin{tabular}{|l|c|c|}
\hline Literacy Level & Male & Female \\
\hline Literate & $07(2.1)$ & $02(0.6)$ \\
Illiterate & $23(6.9)$ & $28(8.4)$ \\
\hline Total & 30 & 30 \\
\hline
\end{tabular}

From the sample studied, 6.9 percent male and 8.4 percent female are illiterate and very few are literate.

\section{Economic Life}

Traditionally the Jenu Kurubas are engaged in collection of honey, herbs, roots, tubers, fruits from the forest which are now prohibited, except for their personal use. Sometimes they are engaged by the contractors in collecting honey and are paid daily wages for the same. Generally the head of the household and other adult members go into the forest to collect honey or other forest produce. The female folk and the young children attend to domestic work and during their spare time they move about on the fringes of the forest to collect edible leaves, roots, bamboo, shoots etc.

In spite of cultivable lands given to them by the government, a large section of them are employed as daily wage labourers. They are also employed by the Forest Department and private contractors for felling trees, collecting bamboo, firewood and other minor forest produce, they are also taken as watchers, guards, fire watchers etc., on daily wage basis.

They are an active people and can endure great hardship in the pursuit of their vocation. They also work as agricultural and plantation labourers in Coffee estates. Sometimes they find employment as road workers and other casual labourers and they are happy with such opportunity.

Earlier they were engaged in a rude type of shifting cultivation known as 'Kamri' and the plot of land brought under such cultivation is called 'thakkal'. Now such cultivation has been restricted by the Forest Department and is brought under teak cultivation. Such lands that have been cultivated since generations are found even 
today near Madenur hadi, where during rainy season cultivation is undertaken. But the crop yield is not assured as the elephants damage it.

The tribal labour were considered cheap and efficient, so the tribal living in the forests were encouraged to continue to stay there, which led to the tribal settlements inside the reserve forests. The Forest Department also tried a combined cultivation of "Sylviculture" that is teak plantation with agricultural practices of the tribal. Wherein every year a plot of land was allotted to a tribal household, for plantation of teak seedlings and carry on cultivation of ragi, jowar etc., on the same plot for two years. So that, he was protecting the seedlings, by looking after his own crops. But this system did not last long, as the tribal was not very hard working, but lazy and lethargic.

Even today, though the men earn, his contribution to the family is only $1 / 3$ of his earnings, rest he spends on drinks. Women are over burdened with workload outside as well as at home. Her contribution of income to the family is hundred percent. Though women are also addicts to drinking, they do not spend their hard earned money like men on it.

One of the important factors to be noticed here is, let it be men or women, they are not worried of tomorrow, if they earn today and spend, they are satisfied. They purchase the items that are needed for the day, eat and drink. They do not store anything for tomorrow. When peeped inside their huts, one does not find any utensils, valuables, rice or dhal stored or any other luxuries. In many a huts, they do not possess even a mat to sleep or sit. This is the situation of our tribes.

When questioned why they are not worried about their future, some of them opined that they are assured of the wages they earn daily, and are not worried about their future. Some women and men responded that if they do not get any thing they go to the forests in search of root and tubers.

They are assured of getting labour in coffee plantation, that they are ready to settle in Coorg for any number of days and work. They have the habit of changing their names and forgetting, as they take advances from the plantation owners and run away back to their home town/village. When the owner comes in search of the tribes, they say, they have not heard such name or person in their community. As all of them have same physical features and resemblance, the owner cannot identify the person and returns back.

It is also observed that, when a team of families, go out as wage labour, few men and women stay back in their respective hadis for taking care of the children, not only their own children but also other's. This is one of the peculiar practices seen only among these tribes, but not in other communities. 


\section{Rehabilitation}

For the last 10-15 years attempts are being made by the Government through Tribal and Social welfare Departments in different areas of the State to rehabilitate and settle the forest dwellers. Many Jenu Kurubas have been benefited by this scheme. Forest land known as "Darkhast Jameen" has been allotted to these tribes and assistance in the form of agricultural implements, bullock carts, seeds, etc have also been provided. Jenu Kurubas neither rears cattle non breed poultry.

In recent years rehabilitation of tribes are also taken up by the Forest Department as a part of the BOTD programmes in co-ordination with other departments, for the conservation of National Park and its Bio-diversity. The Forest Department hardly shows any concession to the tribal in respect of the utilisation of forest produce; rather it provides employment to a large number of tribal labours in connection with the various types of work in the forest. The tribal living inside the forest are efficient labourers and are considered cheap.

Jenu Kurubas settled in agricultural colonies are not completely involved in agriculture. But are found to be engaged as agricultural labourers. Females are mainly involved in cultivation, agricultural labour, and plantation labour; on the other hand males are involved in mining, quarrying, forestry, and construction work.

5. Tribe wise Settlement pattern

\begin{tabular}{|l|c|c|}
\hline Tribe & $\begin{array}{c}\text { Cluster of } \\
\text { Houses }\end{array}$ & $\begin{array}{c}\text { Scattered } \\
\text { Houses }\end{array}$ \\
\hline Jenukuruba & 50 & - \\
Bettakuruba & - & 06 \\
Yerava & - & 04 \\
\hline Total & 50 & 10 \\
\hline
\end{tabular}

6. Tribe wise Housing pattern

\begin{tabular}{|l|c|c|c|c|}
\hline Tribe & $\begin{array}{c}\text { Bamboo wall / } \\
\text { thatched roof }\end{array}$ & $\begin{array}{c}\text { Mud wall / } \\
\text { thatched roof }\end{array}$ & $\begin{array}{c}\text { Mud wall / } \\
\text { tiled roof }\end{array}$ & Total \\
\hline Jenukuruba & 18 & 14 & 18 & 50 \\
Bettakuruba & - & 03 & 03 & 06 \\
Yerava & - & 02 & 02 & 04 \\
\hline Total & .18 & 19 & 23 & 60 \\
\hline
\end{tabular}


Jenu Kurubas as they are not living a secluded life now, and as they are moving out of their settlement for various reasons especially for wage earning, have made contacts with other socially advanced communities of the society and changes have taken place in their socio-cultural aspect.

\section{Life Cycle Ritual}

\section{Birth}

The Jenu Kurubas has given up several of their tribal practices and has adopted some of the customs and practices of other Hindu communities. The first delivery normally takes place in the women's parental home. 'Basira Hosage' is the ceremony performed during 7th month of pregnancy, which is performed only for the first pregnancy. After this she is taken to her natal house.

Some elderly women of the family or the hadi usually attend to the delivery. Now-adays young women at times go to the government hospitals for check ups and take the assistance from the maternity Health Assistants employed by the N.E.S. Blocks. But they do not prefer delivering the child in the hospital, but would prefer at home.

Immediately after delivery, the mother and child are given a bath in warm water. Male child is preferred and considered to be a boon, but if it is a female, still they are not neglected. In many hadis, it is the female children population, which is higher than the male children. A sterile woman is not ill-treated, but after a long wait, if she is unable to bear a child, he can marry another to beget children. But there is no system of adoption. If they do not want one, they live together but do not re-marry.

\section{Tribe wise number of Children}

\begin{tabular}{|l|c|c|}
\hline Tribe & Male & Female \\
\hline Jenukuruba & 65 & 95 \\
Bettakuruba & 08 & 11 \\
Yerava & 12 & 10 \\
\hline Total & 85 & 116 \\
\hline
\end{tabular}

From the above table it is understood that the female childen is more than the male offspring among the tribes.

It is quite interesting to know that the trend of giving birth to 10,12 and in some cases 18 children have vanished and acceptance for planned family have entered 
the mind of the women folk, who in this case are the decision makers. When interviewed some (32 to 35) women who are aged between 30-35 years, except few who have 4 to 5 children, all the others have stopped after 2 or 3 whether it is male orfemale issue.

\section{Puberty}

There are records by Thurston (1975), Luiz (1963) and others, that the girls and women during periodical illness, live outside the limits of the hadi (secluded huts) for three days. After the fourth day the temporary huts in which they live are generally burnt.

These systems have changed drastically and now a days, during their monthly menstruation period the women sit outside their residential huts and there is no common hut outside the hadi built for this purpose.

Only in some cases of the girl attaining puberty a small 'gullu' means (gudisalu in Kannada hut) is built. The girl who sits in the gullu takes hot water bath regularly for 15 days or more. It is customary to give her a new sari and blouse during this ritual. However due to poverty it may not be possible for them to buy new one, she has to go with the old set only. In some cases the girl has to spend her days in the gullu till her parents are able to purchase a new set of clothes.

\section{Marriage}

Earlier marriage by elopement was common among the Jenu Kurubas, and this system of marriage still continues to be practiced by some of them, especially the poorer sections. If a boy and a girl decide to marry, they simply run away into the forest and stay there for 2 to 3 days. They inform their parents of the union only on their return from the forest. Later they were declared as husband and wife.

Though earlier Jenu Kurubas practiced child marriage, now they prefer adult marriage. But, the fact is, as they are illiterate, they are not aware of the actual age and considered adult marriage as a sign of maturity. Pre puberty marriages are not allowed.

When arranged marriages takes place it is preferred with one's father's sister's daughter, mother's brother's daughter and the elder sister's daughter. However marriages usually take place between members of the same hadi, provided the family deities of the boy and the girl to be married are different. Usually the marriage takes place at the boy's village. Soon after marriage, the son and daughter-in-law start living separately in a small hut. The custom of paying Rs. 12/- as bride price 
or otherwise known as 'tera' is not much in practice now. Only those families, which arrange traditional marriages, accept this offer from the boys' parents. Sex relationship outside marriage or before marriage without the intention of marrying are treated as offence and are punished by the Yajaman (tribal head). Except a few cases there is no polygamy or polyandry system. A widower can marry his wife's sister if she is willing. Except widow with grown up children, others can marry. He or she also takes care of his or her earlier children. Divorce is not sought frequently, like all other Hindu Community; they also adjust and live together. Except when it leads to greater quarrel and misunderstanding, when she/he cannot get along, they take the permission of Yajaman and get separated. After separation, if they are willing to marry, re-marriage is allowed. In all these aspects, women do have decision making power and acts accordingly.

Inter tribe marriages are allowed if they are considered to be a section of Kuruba Community. Inter caste marriages usually never takes place, but when questioned the women folk, they were very dare to answer that, if the girl and boy liked each other and they stayed together and wished to continue, community as such may reject them, but as parents, we encourage them to live together and keep up relations. This shows how broad-minded they are.

If it is an unnatural death, like suicide, accident etc. the dead is cremated. Even otherwise they have both the system of cremation or burial. The eldest son is the chief mourner. From our field experience it is understood that male members die early, due to habit of drinking alcohol, lack of timely food and overexertion of work.

\section{Inter-Community and Intra-Community Relationship}

The Jenu Kurubas as they are dependent on agriculture and plantation or farming communities for labour, have always maintained cordial relationships with them. They are not regarded as untouchables and occasionally they avail the services of the barber. The Jenu Kurubas consider themselves superior to Holeyas, Madigas, Balagai etc., and do not accept food from them. They are allowed up to certain limits of all socially advanced castes and eat food given by them.

Its quite interesting to note that, the Jenu Kurubas do not have high or low status, including that of Yajaman who is respected for his post. In their neighbourhood and surroundings the Soligas, Betta Kurubas, Yeravas are considered as co-workers. If they all live together, they help each other on occasions like marriage and also dine (eat) together. But generally Jenu Kuruba always lives independently in their hadis. 


\section{Leisure and Recreation}

'Leisure' is actually spare time or time free from work. Pre modernisation and post modernisation leisure activities are entirely different. In the pre modernisation period, there were no full-fledged playthings, no creative activities for adult and children, time pass entertainment facilities were lacking. Children played with stone or wooden items rudely made. One can remember children playing with a small wooden wheel fixed to a long stick, to run around here and there in the hadi or village. It is a common sight to see boys and girls of both Jenu Kuruba and Betta Kuruba play in front of their dwelling unit or in the other area under trees with stones or tamarind seeds, wooden top, and small round marbles. Other time pass activities are swimming in the nearby pond or pool, tying a rope to the branch of a tree and swinging etc. These leisure activities are common even today among the tribal children.

The Jenu Kurubas have no organized recreation activities or games to be performed during their leisure hours. The adult males and females have little opportunity for leisure and recreation. Their struggle for existence is hard and has to work for the day's meal or starve. Both men and women have to work for their survival, as men contribute very less to the family. Sometimes they seek relief from their feelings through gossip. The women particularly would sit in front of their huts, carry on odd domestic chores and at the same time go on chit chatting. omen time pass recreation is collecting tubers, roots, turmeric, tamarind and other edibles for consumption as well as for survival. But still the inpark tribes enjoy their late evenings before the fire singing and dancing. This is not always but occasionally. Some of them have learnt instruments like drum beating, and pipe an odd type of flute. During festive occasions they have group song and dance. Consuming alcohol and smoking beedis especially by men of both inpark and outside park hadi is common.

Outside Park hadi men are influenced by modern cinema, playing cards, so on. Women once a while go to the nearby tents to see cinema, but not always, as they earn for their living and not for entertainment. Young girls and women have learnt to dress up like other community women, during leisure hours they comb hair, use colourful hair bands, powder their face and use sticker (bindi). Some of them are also undergoing tailoring training. They are aware of modern blouse pattern and stitch one or two for occasions. Small children wear churidar given by other community girls. They are fond of colour tapes, bangles, studs to ear and so on. From their daily income girls spend some amount for such small and cheap cosmetic items. 


\section{The Institution of Social Control and leadership}

Jenu Kurubas has an institution of Yajaman or headmen. But only males can function as their headmen in their hadis. The wife of the Yajaman is also respected. The Yajaman is an important person who attends to all the social, cultural and religious activities held in the hadi. Earlier there was a system that, any stranger could not enter a hadi without his permission. But now things have changed, but still Yajaman is respected.

The Yajaman decides most of the problems, which crop up in the hadi. like family disputes, marriage disputes, divorces, death, birth and naming of the child etc. The Yajaman usually attends any social gathering or meeting. In some hadis they also curse the Yajaman for his non-acceptance of the Government schemes by giving prominence to the non-governmental organisations. In political aspects the Yajaman and whole hadi members decide to which party and to who should they vote.

\section{Environmental Sanitation, Hygiene, Health etc.}

Generally the tribes give least attention to environmental sanitation or personal cleanliness. They do not keep the house and its premises clean. They wear tattered clothes, which are not washed regularly. They do not take bath regularly nor comb hair or wash face properly. They have the habit of chewing beetle leaves and nuts and spitting all around the premises. The children are not given good attention, they are not washed, cleaned or dressed properly, and they are usually in rags or without dress.

The adults and children are mainly attacked by flu, cough, running nose, and skin ailments and is not treated. In some cases indigenous medicines are used if they are aware of. Otherwise they do not go to hospital. If the doctor or nurse visits the hadi, they do not take the medicine properly. During rainy season, the physical environment becomes much unhealthy due to stagnant water in small ditches.

They do not have proper nutrition and food especially the women and children as they are not properly fed. Most of the days they spend on whatever available roots and shoots, as they cannot work, due to sickness and weakness. A man does not pay any attention to his family member's health.

Due to habits of alcoholism, even men are prone to diseases and die much earlier than women. As male mortality is high, more number of female populations is left behind on their own risks. 
They are also believers in sorcery, magic and evil spirits. Women especially are, because, when we were talking of rehabilitation and all Kurubas living together, the female folk did not accept as they said (Kuruba to Kuruba will not get along and if one sees the other getting on well, they use which craft or sorcery to break them). So we do not want to live with other hadi people. When questioned the male members, wanted a good living and did not believe in these aspects.

\section{Social Reform and Welfare Measures}

The main problems faced by the Tribes of the hadis are:

1. Lack of food

2. Lack of clothing

3. Lack of proper housing facility

4. Lack of primary (basic) education

5. Unemployment problem

6. Lack of medical facilities

7. Lack of good drinking water and electricity

8. Threat from forest animals

9. Threat from the forest officials or personnels

10. Social evil like alcoholism etc.

Though attempts were made to reform them by the Tribal Welfare Department of the Government, to raise their economic, social and educational levels, they have failed to fulfill the same. Some colonies were established to help them live a settled life. Darkhast lands were given for cultivation. Wherever possible, implements required for cultivation, bullocks etc have also been supplied. Besides residential schools called Ashrams schools were also started for Jenu Kurubas. Girijan Sammelan a Conference was organised by the Social Welfare Department, once in a year, where important problems were discussed.

Now, though the Forest Department in collaboration with other Departments have come out with high aspirations of rehabilitating them, the tribes are not aware of the actual process of rehabilitation and its merits and demerits. So, they are not willing to come out of the age old tradition of living inside the forest and some who 
are in the clutches of non-governmental organisations, are easily instigated only with the demerits of the scheme, but not the merits.

Interviewing some of the female and male members of the above mentioned hadis, they showed both eagerness and panic about the rehabilitation that is to take place. But still they are aware that Government Programmes are only for the betterment of the community and not for the worst of it. So, they want to gradually come from both the NGO clutches and the traditional feeling of leaving the forest and their hold on its resource and settle a good living and think of their younger generation's future well being and try to live and come up like all other communities of the society.

\section{References}

1. Indira, R.: Gender dynamics in the context of a tribal society, in Pfrffer, G \& Behera, DK (ed.). Contemporary Society: Tribal Studies Vol I. Concept, 1997.

2. Encyclopaedia of Dravidian Linguistics, Vol. II: Tiruvananthapuram, International School of Dravidian Linguistics, 1996.

3. Rao, Nanjunda.: Tribals in Heggada Devana Kote Taluk, (Mysore District), Government of Karnataka, Bangalore, 1988.

4. Census of India: Karnataka Primary Census Abstract to Scheduled Castes and Scheduled Tribes, Series 9, Part 2 B(2). New Delhi, 1981.

5. Misra, P.K.: The Jenu Kuruba, Primitive Tribes, Government of India, New Delhi, 1977.

6. Misra, P.K.: Jenu Kuruba, Bulletin, Anthropological Survey of India, 18(3), 1975.

7. Misra, P.K.: Economic Development among the Jenu Kuruba, Man in India, 50(1),1970.

8. Luiz, A.A.D: The Tribes of Mysore, Bangalore Government Press, 1963.

9. Mann, R.S.: Social change and the Status of Tribal Women, Social Welfare, Vol. 14, 1963.

10. Luiz, A.A.D.: The Tribes of Kerala, Bharathiya Adimiati Sevak Sangh, New Delhi, $1962 .$.

11. Thurston, E.: Castes and Tribes of Southern India, (Reprint 1975) Vol. IV, Govt. Press, Madras, 1909. 